\title{
PEMETAAN WILAYAH LAHAN KERING MENGGUNAKAN DATA PENGINDERAAN JAUH
}

\author{
Arthur Gani Koto \\ Program Studi Geografi Fakultas Sains dan Teknologi Universitas Muhammadiyah \\ Gorontalo \\ email : arthur@umgo.ac.id
}

\begin{abstract}
Dry land occupies the largest area (90\%) and has a strategic position in agricultural development activities in Indonesia. The biggest potential of natural resources in the agricultural sector in the district was reached $40.26 \%$. One of the data provider of effective and efficient in terms of development activities and development of the region is remote sensing data. The purpose of this study is to map the area of dry land with the help of remote sensing data. Landsat imagery 8 extracted to obtain land cover information which is then further processed to produce a land use classification is based on the knowledge based classification. Analyzed land use to obtain the map of dry land. The results showed that the District of Wonosari has an area of dry land scattered in all districts and has an area of $185.733 \mathrm{~km}^{2}$. Dry land area consists of mixed farms $\left(162.811,8 \mathrm{~km}^{2}\right)$ and bare land $\left(22.921,2 \mathrm{~km}^{2}\right)$.
\end{abstract}

Keywords : dry land, remote sensing, mapping, landsat 8

\begin{abstract}
Abstrak
Tanah kering menempati area terbesar (90\%) dan memiliki posisi strategis dalam kegiatan pembangunan pertanian di Indonesia. Potensi sumber daya alam terbesar di sektor pertanian di kabupaten ini mencapai $40,26 \%$. Salah satu penyedia data yang efektif dan efisien dalam hal kegiatan pengembangan dan pengembangan kawasan adalah data penginderaan jauh. Tujuan dari penelitian ini adalah untuk memetakan daerah lahan kering dengan bantuan data penginderaan jarak jauh. Citra landsat 8 diekstraksi untuk mendapatkan informasi tutupan lahan yang kemudian diproses lebih lanjut untuk menghasilkan klasifikasi penggunaan lahan berdasarkan klasifikasi berbasis pengetahuan. Menganalisis penggunaan lahan untuk mendapatkan peta lahan kering. Hasil penelitian menunjukkan bahwa Kabupaten Wonosari memiliki lahan kering yang tersebar di semua kecamatan dan memiliki luas wilayah $185.733 \mathrm{~km} 2$. Luas lahan kering terdiri dari lahan pertanian campuran $(162,811,8 \mathrm{~km} 2)$ dan lahan kosong (22.921,2 km2).

Kata kunci: lahan kering, penginderaan jarak jauh, pemetaan, landsat 8
\end{abstract}




\section{PENDAHULUAN}

Lahan kering menempati areal yang terluas dan punya kedudukan yang strategis dalam kegiatan pembangunan pertanian di Indonesia. Pemanfaatan lahan kering merupakan sarana penting dalam usaha pemerataan pembangunan. Lahan kering merupakan penghasil berbagai komoditas pertanian seperti pangan, sandang, perkebunan, perumahan, obat-obatan, disamping sebagai penghasil devisa (Wikantika dan Agus, 2006).

Pemanfaatan

teknologi

penginderaan jauh dengan menggunakan citra satelit Landsat merupakan salah satu alternatif untuk wilayah Indonesia dalam usaha memperoleh informasi sumber daya pertanian, khususnya luas tanaman pertanian secara cepat dan akurat (luas cakupan $185 \mathrm{~km} \times 185 \mathrm{~km}$ ). Satelit Landsat dilengkapi dengan sensor yang dapat merekam setiap objek di permukaan bumi yang memantulkan atau memancarkan energi elektromagnetik dari ketinggian tertentu. Citra satelit penginderaan jauh dapat menggantikan survei terestris yang memerlukan waktu lama dan biaya yang relatif tinggi.

Kecamatan Wonosari merupakan salah satu wilayah di Kabupaten Boalemo yang mempunyai potensi sumber daya alam yang besar, terlebih di sektor pertanian. Data BPS Kabupaten Boalemo 2011 menunjukkan bahwa perekonomian didominasi oleh sektor pertanian
(40.26\%), sektor jasa-jasa (23.07\%) serta sektor perdagangan, hotel, dan restoran (10.50\%).

Tujuan penelitian ini adalah untuk memetakan wilayah lahan kering dengan bantuan data penginderaan jauh.

\section{METODE PENELITIAN Bahan dan Alat}

Bahan yang digunakan pada penelitian ini adalah Citra Landsat 8 level L1T perekaman tanggal 20 April 2013 dan Peta Digital BPSKEMENTAN.

Alat yang digunakan yaitu Notebook ASUS K43T (Prosesor AMD A6 3420M, RAM 6 GB, VGA Card AMD RADEON HD 6520G, HDD Seagate $500 \mathrm{~GB}$ ), GPS Garmin Oregon 650, software pengolah citra digital : ENVI 5.02 dan ILWIS 3.3 Academic, software pengolah kata : WPS Writer 2014 Beta 3.

Penelitian dilakukan di Kecamatan Wonosari, Kabupaten Boalemo, Propinsi Gorontalo yang memiliki luas $184.229 \mathrm{~km}^{2}$. Selengkapnya tersaji pada Gambar 1. Penelitian menggunakan citra Landsat 8 dan analisis spasial (SIG). Teknik pengolahan citra yang dilakukan yaitu penggabungan saluran (image stacking), pemotongan citra, dan klasifikasi supervised menggunakan metode Support Vector Machines (SVM). 


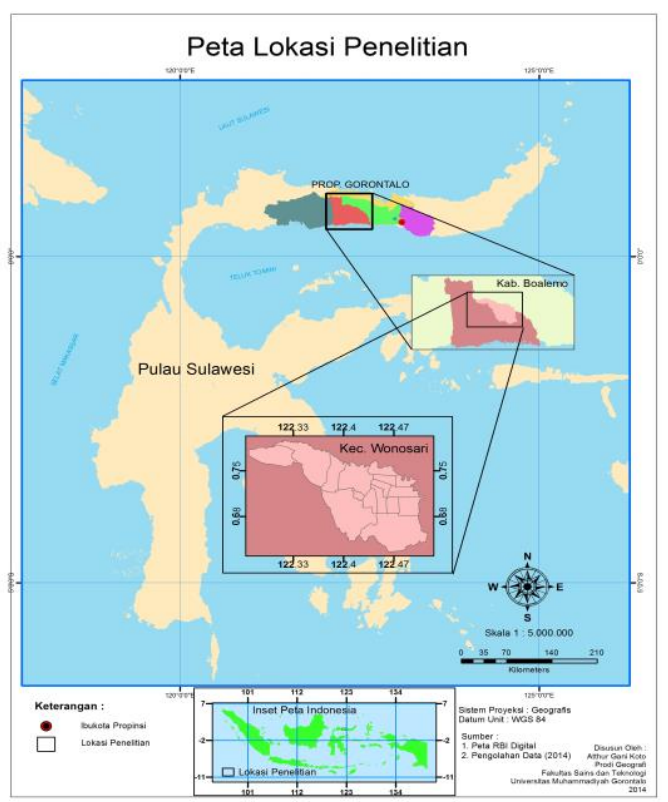

Gambar 1 Peta lokasi peneltian

Tahapan pengolahan citra digital dibagi dua tahap yaitu pre processing citra (penggabungan saluran, pemotongan citra), pengolahan citra digital dan klasifikasi supervised metode SVM.

Kelas klasifikasi dibuat sesuai dengan kebutuhan dan karakteristik wilayah Kecamatan Wonosari. Klasifikasi citra dianalisis menjadi dua tahap yaitu klasifikasi penutup lahan dan penggunaan lahan. Kelas klasifikasi penutup lahan dibagi menjadi hutan, tanah air dangkal, kebun campuran, dan lahan terbuka. Sedangkan kelas klasifikasi penggunaan lahan diekstrak berdasarkan klasifikasi penutup lahan dan pengetahuan lapangan. Penentuan potensi lahan kering diperoleh dari hasil analisis penggunaan lahan.

\section{HASIL DAN PEMBAHASAN}

\section{Pemrosesan Citra Landsat}

Citra Landsat 8 yang diperoleh masih terdiri atas saluran-saluran tersendiri. Penggabungan saluran menjadi satu file citra dilakukan dengan tujuan agar dapat dilakukan klasifikasi citra secara digital. Analisis secara visual, citra dapat dibuat dalam komposit-komposit warna yang diinginkan. Landsat 8 yang dilakukan proses penggabungan saluran, hanya yang memiliki resolusi spasial yang sama yaitu $30 \mathrm{~m}$, mulai dari saluran 1 7 dan saluran 9 sampai 11 . Saluran 8 merupakan saluran panchromatic $(15 \mathrm{~m})$. Sedangkan saluran 10 sampai 11 (band thermal) ketika citra diunduh, memiliki resolusi spasial $30 \mathrm{~m}$.

Tahap selanjutnya setelah penggabungan saluran, dilakukan proses pemotongan citra sesuai wilayah kajian. Pemotongan citra ini dilakukan dengan overlay Peta Digital BPS-KEMENTAN, sehingga diperoleh citra khusus wilayah Kecamatan Wonosari.

Klasifikasi penutup lahan/penggunaan lahan pada wilayah penelitian menggunakan false color composite (753), dan color infrared (543). Penajaman citra menggunakan teknik perentangan kontras. Teknik perentangan kontras dilakukan agar secara visual memperlihatkan penampakan citra yang lebih jelas dan dapat memperjelas kenampakan obyek 
permukaan bumi. Contoh teknik perentangan kontras disajikan pada Gambar 2.
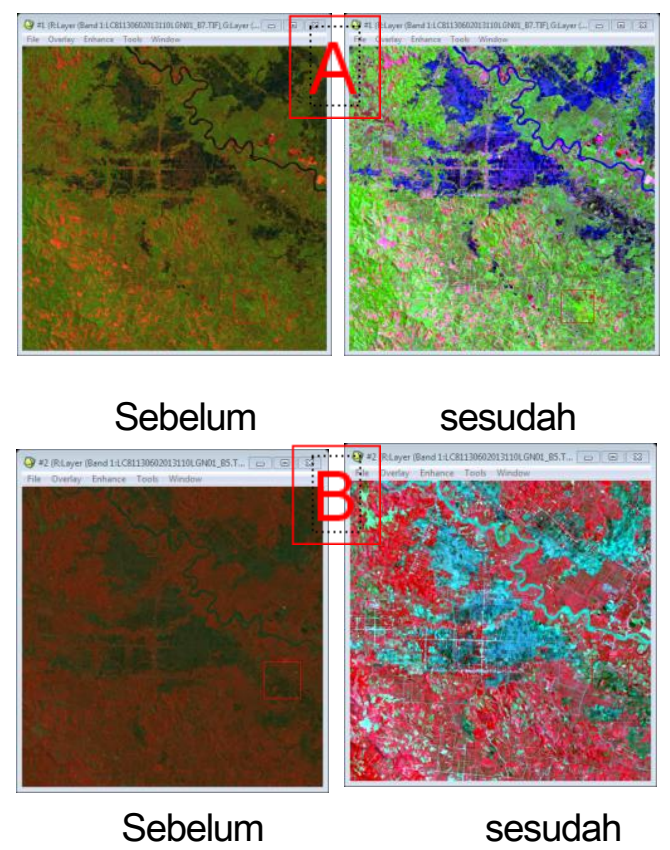

Gambar 2 Teknik perentangan kontras. a) false color composite 753, b) color infrared 543

\section{Klasifikasi Penggunaan Lahan}

Klasifikasi

multispektral menggunakan metode SVM menghasilkan lima jenis penggunaan lahan saat ini, yaitu : hutan, lahan terbuka, sawah, kebun campuran dan tubuh air. Klasifikasi penggunaan lahan saat ini disajikan pada Tabel 2 dan peta penggunaan lahan saat ini disajikan pada Gambar 3.

Kecamatan Wonosari berada pada ketinggian 30-330 mdpl dan mempunyai kemiringan lereng yang didominasi relatif datar.
Tabel 2. Luas penggunaan lahan

\begin{tabular}{|c|c|}
\hline $\begin{array}{l}\text { Penggunaan } \\
\text { lahan }\end{array}$ & $\begin{array}{l}\text { Luas } \\
\left(\mathrm{km}^{2}\right)\end{array}$ \\
\hline Tubuh air & $13.169,700$ \\
\hline Sawah & $9.873,000$ \\
\hline Kebun campuran & $133.103,700$ \\
\hline hutan & $24.780,600$ \\
\hline Lahan terbuka & $47.361,600$ \\
\hline Luas total & $228.288,600$ \\
\hline
\end{tabular}

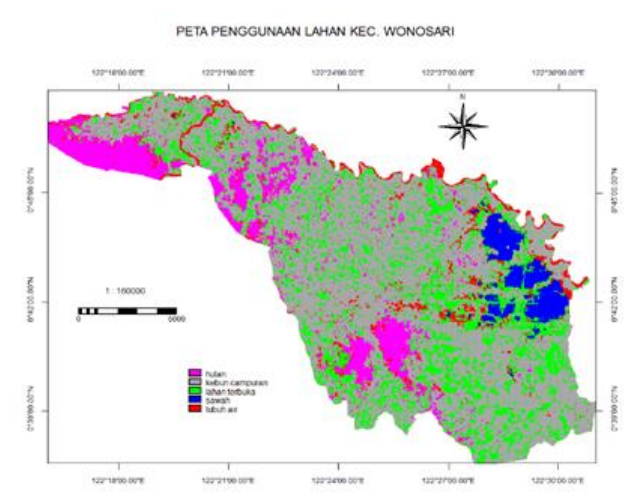

Gambar 3. Peta penggunaan lahan Kec. Wonosari

Klasifikasi penggunaan lahan tubuh air terdiri atas sungai dan air dangkal. Air dangkal terdapat pada lahan persawahan sebab perekaman satelit landsat 8 terjadi pada waktu musim tanam padi sehingga sawah diklasifikasikan sebagai tanah yang tergenang air. Tubuh air menempati luas wilayah 13.169,7 km². Lahan persawahan nampak berupa tanaman padi yang baru tumbuh.

Kebun campuran yang terdapat di wilayah penelitian berupa tanaman 
jagung, kelapa, dan kakao. Kebun campuran menempati luas wilayah terbesar pada Kecamatan Wonosari, yaitu $133.103,7 \mathrm{~km}^{2}$.

Penggunaan lahan sawah memiliki luas wilayah $9.873 \mathrm{~km}^{2}$. Kenampakan lahan persawahan pada citra Landsat 8 berupa lahan relatif datar, tanaman padi yang baru tumbuh, dan pada beberapa lahan masih tergenang air. Komposit citra false color composite 567 lahan persawahan nampak berwarna kehitaman dan keabu-abuan mirip dengan kenampakan tubuh air (sungai).

Hutan menempati luas wilayah 24.780,6 km². Hutan di wilayah penelitian dimasukkan dalam kategori hutan lebat dan berada pada wilayah ketinggian 80 mdpl keatas. Komposit citra false color composite 567 lahan hutan namapak berwarna coklat gelap.

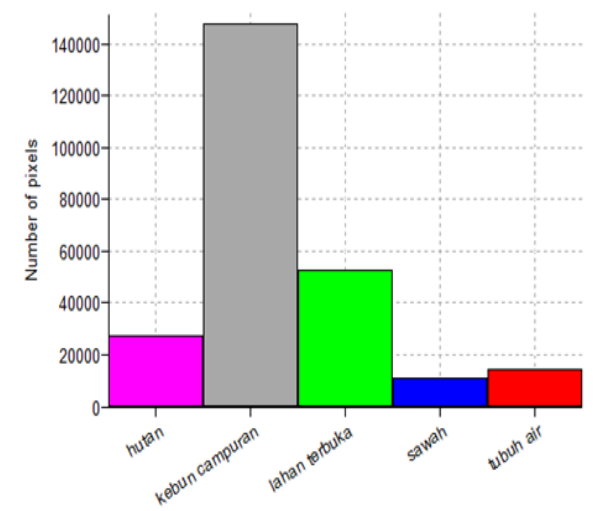

Gambar 4. Penggunaan lahan berdasarkan jumlah piksel

Klasifikasi lahan terbuka menempati luas wilayah 47.361,6 $\mathrm{km}^{2}$. Penggunaan Lahan hutan dominan terdapat pada wilayah sebelah barat Kecamatan Wonosari yang berbatasan dengan Kecamatan
Dulupi.

lahan terbuka terdapat hampir diseluruh Kecamatan Wonosari yang didominasi tanaman semak belukar, lahan kosong, dan tanaman hortikultura. Menggunakan citra komposit FCC 567, lahan terbuka nampak berwarna keputihan dengan nilai pantulan yang tinggi.

Diagram jumlah piksel untuk tiap penggunaan lahan di Kecamatan Wonosari disajikan pada Gambar 4.

\section{Klasifikasi Lahan Kering}

Budidaya pertanian tanaman pangan dikelompokkan menjadi dua bagian yaitu pertanian lahan basah (sawah) dan pertanian lahan kering. Klasifikasi lahan kering dilakukan dengan menggunakan perangkat lunak pengolah citra (image processing) ILWIS 3.3 Academic. Pada klasifikasi penggunaan lahan, Kecamatan Wonosari dibagi atas 5 kelas penggunaan lahan, yaitu hutan, kebun campuran, tubuh air, sawah, dan lahan terbuka.

Berdasarkan klasifikasi penggunaan lahan, maka dapat disimpulkan bahwa wilayah lahan kering bukan merupakan wilayah pertanian lahan basah (sawah), hutan dan tubuh air.

Hasilnya yaitu peta lahan kering dalam bentuk raster, yang terbagi atas dua kelas yaitu lahan kering dan non lahan kering (sawah, tubuh air, dan hutan). Lahan kering diklasifikasikan terdiri atas pengunaan lahan kebun campuran dan lahan terbuka. Luas total lahan kering pada kecamatan Wonosari berkisar $185.733 \mathrm{~km}^{2}$. 
Wilayah lahan kering terdapat hampir pada seluruh Kecamatan Wonosari dan didominasi pada topografi yang relatif datar. Klasifikasi lahan kering disajikan pada Tabel 1. Peta wilayah lahan kering disajikan pada Gambar 5.

\begin{tabular}{|c|c|}
\hline $\begin{array}{c}\text { Penggunaan } \\
\text { Lahan }\end{array}$ & Luas $\left(\mathrm{km}^{2}\right)$ \\
\hline Tubuh air & $7.878,6$ \\
\hline Sawah & $12.590,1$ \\
\hline Lahan kering & 185.733 \\
\hline Hutan & $22.086,9$ \\
\hline Luas total & $228.288,6$ \\
\hline
\end{tabular}

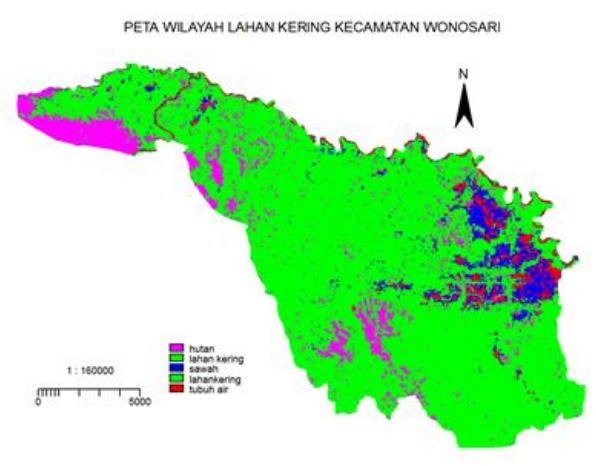

Gambar 5. Peta wilayah lahan kering Kec. Wonosari

\section{SIMPULAN DAN SARAN}

\section{Simpulan}

Hasil penelitian menunjukkan bahwa data penginderaan jauh dapat digunakan untuk memetakan wilayah lahan kering. Kecamatan Wonosari memiliki wilayah lahan kering yang tersebar pada seluruh kecamatan dan memiliki luas 185733 km². Wilayah lahan kering terdiri atas kebun campuran $\left(162.811 .8 \mathrm{~km}^{2}\right)$ dan lahan terbuka (22. $921.2 \mathrm{~km}^{2}$ ). Wilayah non lahan kering terdiri atas penggunaan lahan hutan (22 $086.9 \mathrm{~km}^{2}$ ), tubuh air $\left(7.878,6 \mathrm{~km}^{2}\right)$ dan sawah (12 590.1 $\left.\mathrm{km}^{2}\right)$.

\section{Saran}

Kebutuhan manusia berupa bahan pangan semakin bertambah seiring dengan pertambahan penduduk dan ketersediaan lahan pertanian. Dalam pengelolaan dan pengembangan lahan pertanian, salah satu hal yang diperlukan tentunya ketersediaan lahan, dimana hal ini dapat dikembangkan dengan kelengkapan data berupa data berbasis keruangan/spasial

Penelitian ini hanya menggunakan citra satelit penginderaan jauh Landsat 8. Diperlukannya data seperti kemiringan lereng, kemampuan lahan, curah hujan, elevasi, dan jenis tanah dapat memperkaya hasil penelitian.

\section{DAFTAR PUSTAKA}

BPS Kabupaten Boalemo. 2011.

Kabupaten Boalemo Dalam Angka

Danoedoro, Projo. 2008. Physical Planning and the Need for Versatile Land-Use Information : A Geoinformation Technology Perspective on the Classification System

Danoedoro, Projo. 2010. Pengantar Penginderaan Jauh Digital. Penerbit Andi. Yogyakarta

Kerami, D., dan H. Murfi. 2004. Kajian

Kemampuan 
Generalisasi Support Vector Machine Dalam Pengenalan Jenis Splice Sites Pada Barisan DNA. Makara Sains, Vol. 8, 89-95

Koto, Arthur Gani. 2012. Pemanfaatan Teknologi Penginderaan Jauh dan SIG untuk Evaluasi Lahan Kering di Kab. Bantaeng, Sulawesi Selatan. Tesis. Fakultas Geografi Universitas Gadjah Mada Yogyakarta

Mather, P. M., and M. Koch. 2011. Computer Processing of Remotely-Sensed Images. John Wiley \& Sons, Ltd., UK Minardi. 2009. Optimalisasi Pengelolaan Lahan Kering Untuk Pengembangan Pertanian Tanaman Pangan. Pidato Pengukuhan Guru Besar Ilmu Tanah pada Fakultas Pertanian Universitas Sebelas Maret. Universitas Sebelas Maret, Surakarta Notohadiprawiro, T. 1989. Pertanian Lahan Kering Di Indonesia : Potensi, Prospek, Kendala dan Pengembangannya. Lokakarya Evaluasi Pelaksanaan Proyek Pengembangan Palawija. Bogor

Rukmana, Rahmat. 1995. Teknik Pengelolaan Lahan Berbukit dan Kritis. Kanisius. Jakarta Wikantika, K., dan A. Agus. 2006. Analisis Perubahan Luas Pertanian Lahan Kering Menggunakan Transformasi Tasseled Cap (Studi Kasus :
Kawasan Puncak-Jawa Barat). Jurnal Infrastruktur dan Lingkungan Binaan, Vol. II No. 1 